\title{
Evaluation of propane flaming for reducing bacterial counts in sand bedding
}

\author{
J. S. Hogan, ${ }^{1}$ L. Raubenolt, J. L. McCormick, and W. P. Weiss \\ Department of Animal Sciences, The Ohio State University, Ohio Agricultural Research and Development Center, Wooster 44691
}

\begin{abstract}
An experiment was conducted on a commercial dairy farm to determine the effects of propane flaming on bacterial populations of common environmental mastitis pathogens in recycled sand bedding. One row of freestalls was flamed within $12 \mathrm{~h}$ after recycled bedding was added to stalls and then daily for the next $6 \mathrm{~d}$. Bedding in a control row of freestalls was untreated. Stalls received the same treatment for 3 consecutive weeks. After $3 \mathrm{wk}$, bedding treatments were changed between rows in a switchback design. The daily movement of the $760^{\circ} \mathrm{C}$ propane-fueled flame at $3.2 \mathrm{~km} / \mathrm{h}$ over the surface of recycled sand bedding in stalls had a positive effect by reducing mastitis pathogen loads at different depths of bedding in a pathogen-specific manner. The greatest reduction of mastitis pathogen populations by flaming was on the surface $25 \mathrm{~mm}$ of recycled sand. Reductions in bacterial counts in deeper layers were less consistent. Bacterial populations in both flamed and control sand bedding were lower on the surface $25 \mathrm{~mm}$ compared with sand at a depth of 50 to $75 \mathrm{~mm}$. The effects of subsequent flaming of sand over a week also differed among pathogens. In general, mastitis pathogens were reduced the most on the day that recycled sand was added to stalls, and flaming was less effective as sand bedding was in stalls over a 6 -d period. The use of propane flaming of recycled sand was shown to have potential as a practice to control mastitis pathogen populations in bedding. The greatest advantage afforded by flaming was on the surface of bedding, with inconsistent effects deeper in the stalls. Flaming was more effective in controlling bacterial populations in fresh recycled sand than in sand after several days use.
\end{abstract}

Key words: sand bedding, propane flame, mastitis

\section{INTRODUCTION}

A key to controlling mastitis is identification of sources of the bacteria causing infections and reduction

Received February 23, 2012.

Accepted May 30, 2012.

${ }^{1}$ Corresponding author: hogan.4@osu.edu of exposure of cows to mastitis pathogens. A primary source of environmental mastitis pathogens in the cow's habitat is the bedding or material used for cows to lie on in stalls or corrals (Hogan and Smith, 1997; Zdanowicz et al., 2004). The use of sand as bedding for dairy cows dramatically reduces exposure of teat ends to coliform mastitis pathogens compared with common organic bedding materials (Hogan et al., 1989; Zdanowicz et al., 2004). The effectiveness of sand in reducing exposure of mastitis pathogens to mammary glands is due to its inorganic properties. On-farm recycling of bedding by separating sand from manure reduces bedding costs and aids the environmental sustainability of farms by decreasing over-the-road cartage costs and soil compaction of farmland. However, the subsequent use of sand reclaimed from passive water-settling ponds or mechanical separation may result in increased exposure of cows to pathogens. As organic content and moisture in sand bedding increases during the common practice of on-farm reclamation of sand from manure, the mastitis pathogen populations may also increase (Kristula et al., 2005). The need exists for environmentally safe and effective procedures for altering the physical properties and bacterial loads in recycled sand bedding. The use of propane flame for reducing pathogen populations in poultry litter has been reported as a practical means of sanitizing animal contact areas without adding potentially toxic chemicals to the environment (Raffaelli et al., 2010). Therefore, the purpose of the current trial was to determine the effects of propane flaming of sand bedding on bacteriological populations of common environmental mastitis pathogens.

\section{MATERIALS AND METHODS}

\section{Experimental Design}

The experiment was conducted on a commercial farm of approximately 600 lactating cows housed in freestall barns. Cows were bedded on sand recycled from passive-separation settling lanes. Each stall was bedded to a minimum depth of $150 \mathrm{~mm}$ of sand. Sand was added to all stalls to a minimum depth of $150 \mathrm{~mm}$ each Monday evening. One row of freestalls was flamed within $12 \mathrm{~h}$ after fresh bedding was added to stalls and 
then daily for the next $6 \mathrm{~d}$. One row of freestalls was the untreated control. Stalls received the same treatment for 3 consecutive weeks. After 3 wk on a bedding treatment, bedding treatments were changed between rows. The trial lasted $6 \mathrm{wk}$ so that stalls were exposed to both bedding treatments in a switchback design to account for differences among stalls.

\section{Flaming Unit}

The prototype flaming unit (Dairy Dragon, Flame Engineering, Lacrosse, KS) was mounted to a rake attached to a $50-\mathrm{hp}$ tractor. The hydraulically controlled rake, equipped with tines approximately $75 \mathrm{~mm}$ long, tilled bedding $150 \mathrm{~mm}$ preceding the flame. Control sand was also tilled daily with the $75-\mathrm{mm}$ tines, but was not flamed. The flaming unit wand consisted of 3 burners spaced $30.5 \mathrm{~cm}$ apart on a $1-\mathrm{m}$ wand. Each burner produced a $760^{\circ} \mathrm{C}$ propane-fueled flame. The flaming unit was operated according to manufacturer's instruction at a traveling speed of $3.2 \mathrm{~km} / \mathrm{h}$.

\section{Bedding Samples}

Sample Collection. Samples were collected from both flamed and control stalls immediately after sand was flamed (d 0) and immediately before flaming 1, 2, and $6 \mathrm{~d}$ later. Samples represent the effects of flaming immediately after treatment (d 0) and the accumulative effects of flaming $24 \mathrm{~h}$ after treatment (d 1, 2, and 6 ) for $1 \mathrm{wk}$. Samples analyzed were daily composites of bedding from the surface $25 \mathrm{~mm}$ and at depths of 25 to $50 \mathrm{~mm}$ and 50 to $75 \mathrm{~mm}$ of sand from the back one-third of each of the 4 stalls within treatment group. Sand samples were collected as bore samples using a modified $60-\mathrm{mL}$ sterile syringe.

Moisture and $O M$. Twenty-five grams of composite sample was placed in a convection oven at $100^{\circ} \mathrm{C}$ for 12 $\mathrm{h}$ to determine moisture content of samples. Following moisture determination, crucibles containing bedding were heated to $600^{\circ} \mathrm{C}$ for $12 \mathrm{~h}$ to determine OM content.

Bacterial Counts. Bacterial populations in bedding were enumerated by adding $10 \mathrm{~g}$ of sample to $90 \mathrm{~mL}$ of sterile PBS and mixing the solution for 40 s. Serial dilutions of the liquid phase in sterile PBS were plated on the surface of MacConkey agar (Becton Dickinson Microbiology Systems, Cockeysville, MD), MacConkey-inositol-carbenicillin agar, and modified Edwards agar containing $5 \mathrm{mg} / \mathrm{L}$ colistin sulfate and $2.5 \mathrm{mg} / \mathrm{L}$ oxolinic acid (Becton Dickinson Microbiology Systems). Inositol (10 mg/L; Sigma Chemical Co., St. Louis, MO) and carbenicillin $(75 \mathrm{mg} / \mathrm{L}$; Pfizer Co., New York, NY) were added to MacConkey agar for MacConkey-inositol-carbenicillin agar. Bovine plasma
$(50 \mathrm{~mL} / \mathrm{L})$ was substituted for whole blood to prepare modified Edwards medium. Serial dilutions plated on all media were $1: 10^{2}$ to $1: 10^{6}$. Inoculated plates were incubated for $24 \mathrm{~h}$ at $37^{\circ} \mathrm{C}$. Colony-forming units per gram were identified as gram-negative bacteria (total growth on MacConkey agar), coliforms (lactose-positive colonies on MacConkey agar), Klebsiella spp. (pink to red colonies on MacConkey-inositol-carbenicillin agar), or streptococci (total growth on modified Edwards agar). Bacterial counts were expressed as $\log _{10}$ per gram of bedding.

\section{Statistical Analyses}

Bacterial counts, moisture, and OM content were analyzed by least-squares ANOVA using the mixed procedure of SAS (SAS Institute, 2003). The main effects for each variable were treatment, sample depth, sample day, and week of period. Main effects and possible 2-way interactions were tested. Significance was defined as $P<0.05$.

\section{RESULTS}

\section{Flaming}

Streptococcal counts were reduced in treated sand bedding immediately after treatment in the surface 25 $\mathrm{mm}$ (Figure 1; $P<0.01$ ), 25 to $50 \mathrm{~mm}$ (Figure 2; $P$ $<0.05$ ), and 50 to $75 \mathrm{~mm}$ (Figure $3 ; P<0.01$ ) layers. Streptococcal counts were reduced in treated sand bedding on $\mathrm{d} 1$ in the surface $25 \mathrm{~mm}(P<0.05), 25$ to 50 $\mathrm{mm}(P<0.05)$, and 50 to $75 \mathrm{~mm}(P<0.05)$ layers. Flaming did not affect $(P>0.05)$ streptococcal counts on $\mathrm{d} 2$ or $\mathrm{d} 6$.

The use of propane flaming reduced total gram-negative bacterial counts in the surface $25 \mathrm{~mm}(P<0.05)$ and 50 to $75 \mathrm{~mm}(P<0.01)$ layers of recycled sand bedding on d 1. Gram-negative counts did not differ $(P>0.05)$ between flame-treated and control bedding immediately after treatment, or on d 2 or 6 in any of the 3 layers of bedding sampled.

Coliform counts were reduced in the 50 to $75 \mathrm{~mm}(P$ $<0.05)$ layer of treated bedding compared with control bedding immediately after flaming. No other differences in coliform counts were significant $(P>0.05)$ when comparing treated with control bedding in the 3 layers of bedding sampled.

Klebsiella spp. counts were reduced by flaming compared with untreated sand in the surface $25 \mathrm{~mm}(P<$ $0.05)$ of bedding immediately after treatment and on d 1. Klebsiella spp. counts did not differ $(P>0.05)$ between control and treated bedding in the 25 to 50 or 50 to $75 \mathrm{~mm}$ layers. 
HOGAN ET AL.
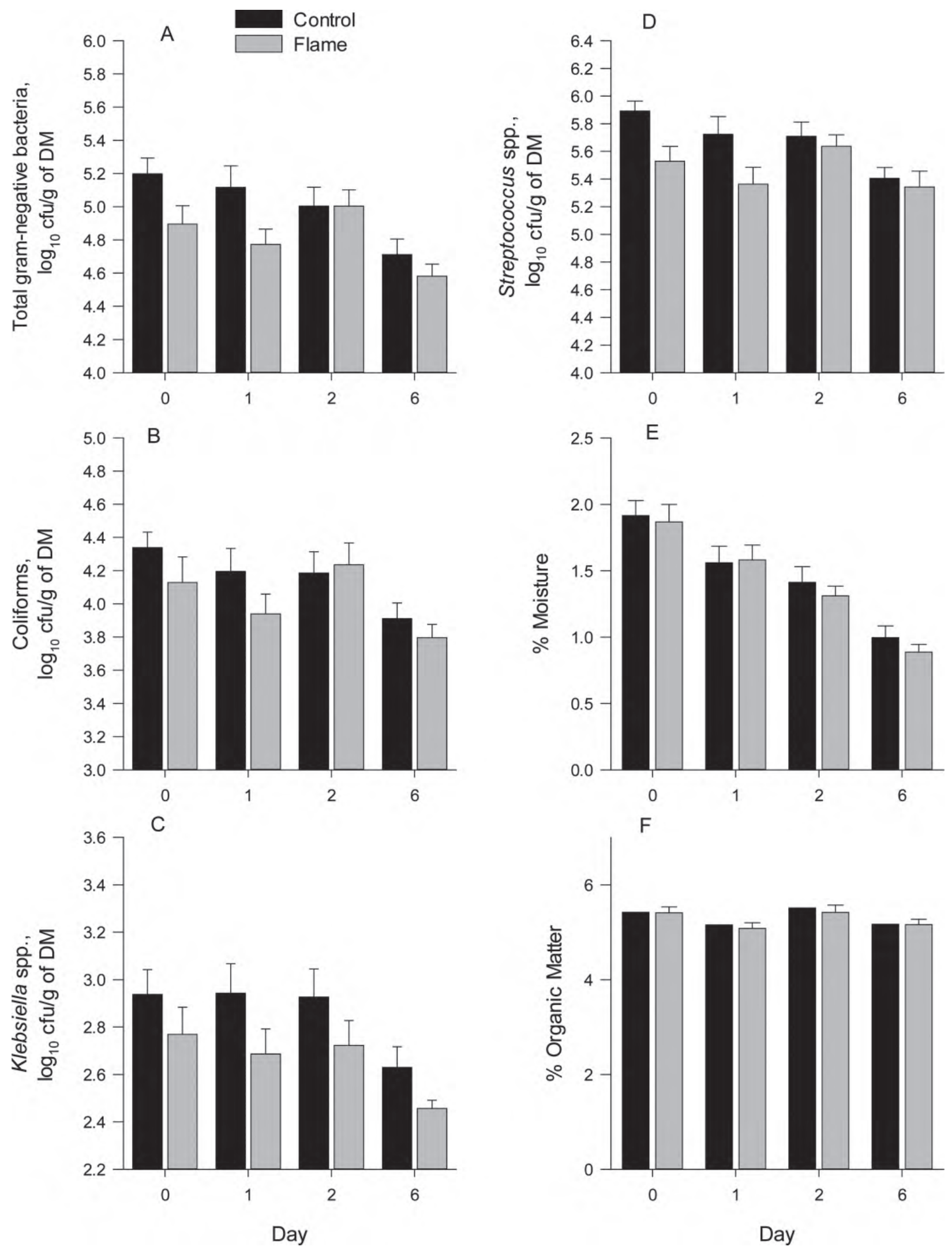

Figure 1. Counts of (A) gram-negative bacteria, (B) coliforms, (C) Klebsiella spp., (D) Streptococcus spp., (E) moisture, and (F) organic matter in the surface $25 \mathrm{~mm}$ of untreated sand and sand treated with propane-fueled flame on d $0,1,2$, and 6 after use as bedding in freestalls. 

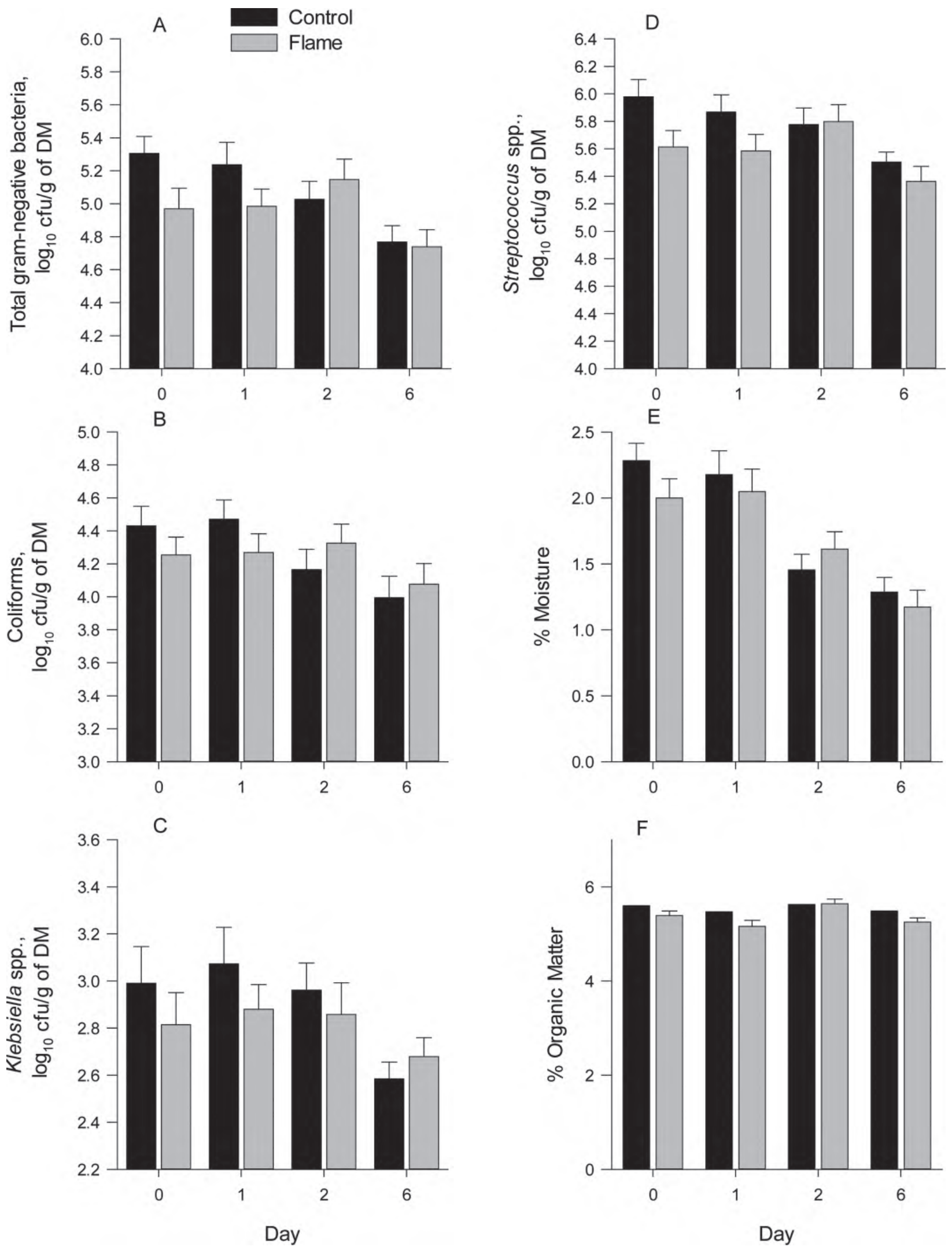

Figure 2. Counts of (A) gram-negative bacteria, (B) coliforms, (C) Klebsiella spp., (D) Streptococcus spp., (E) moisture, and (F) organic matter at a depth of 25 to $50 \mathrm{~mm}$ of untreated sand and sand treated with propane-fueled flame on d $0,1,2$, and 6 after use as bedding in freestalls. 


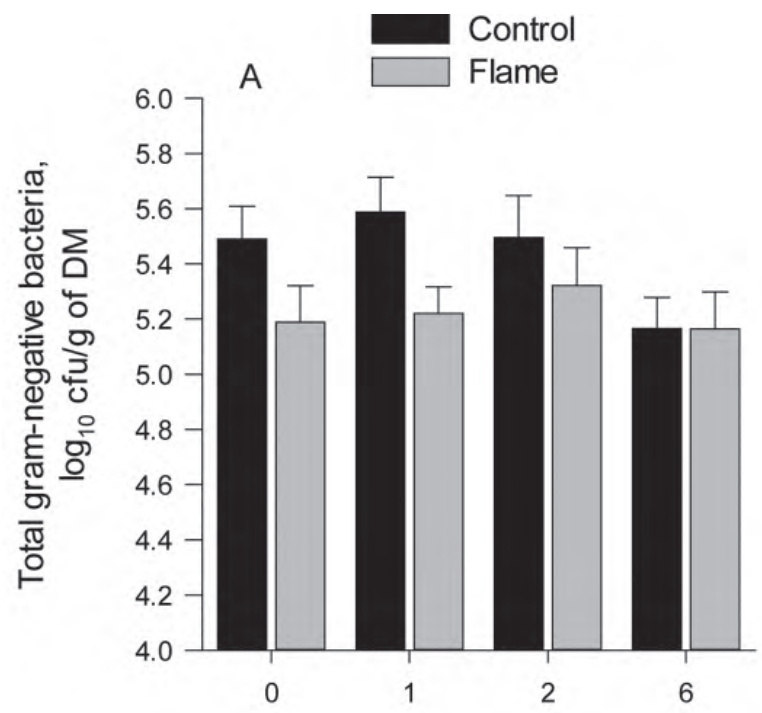

B
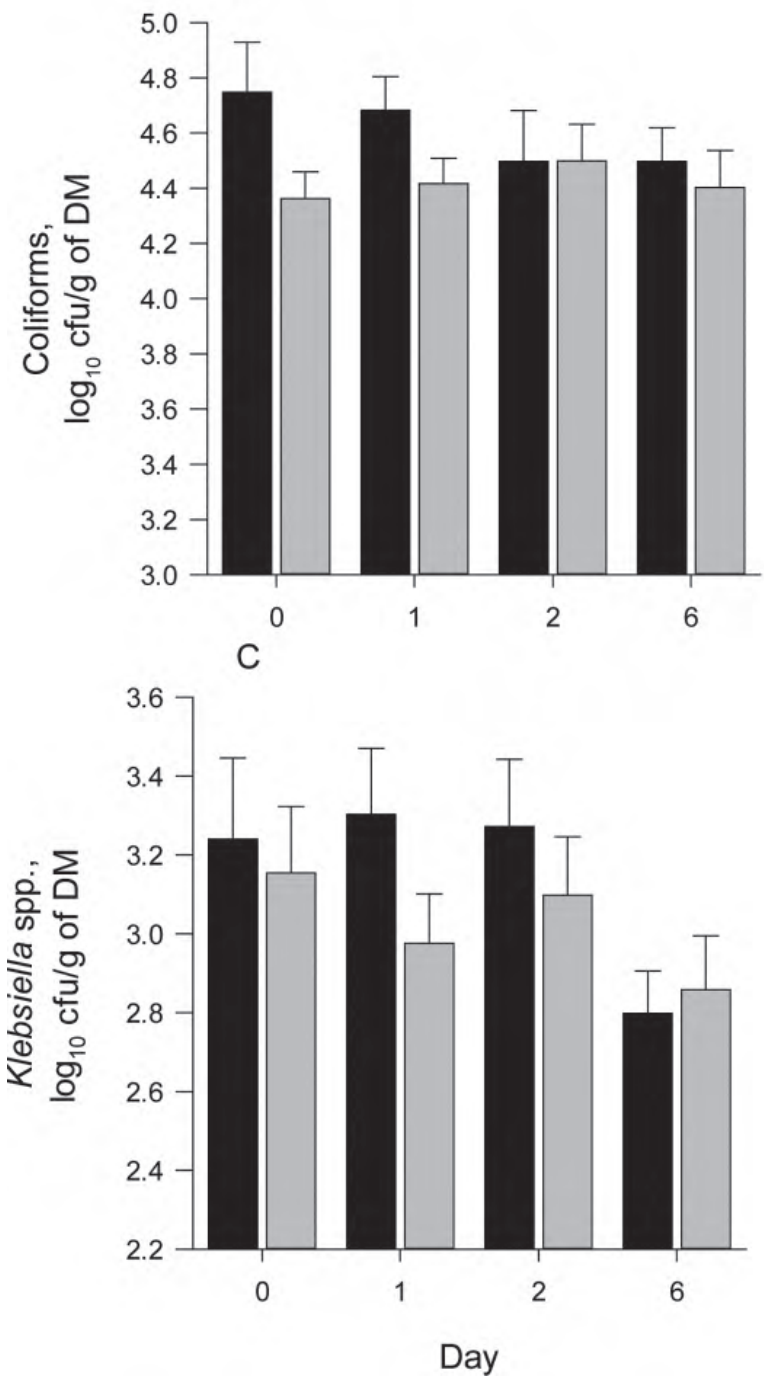
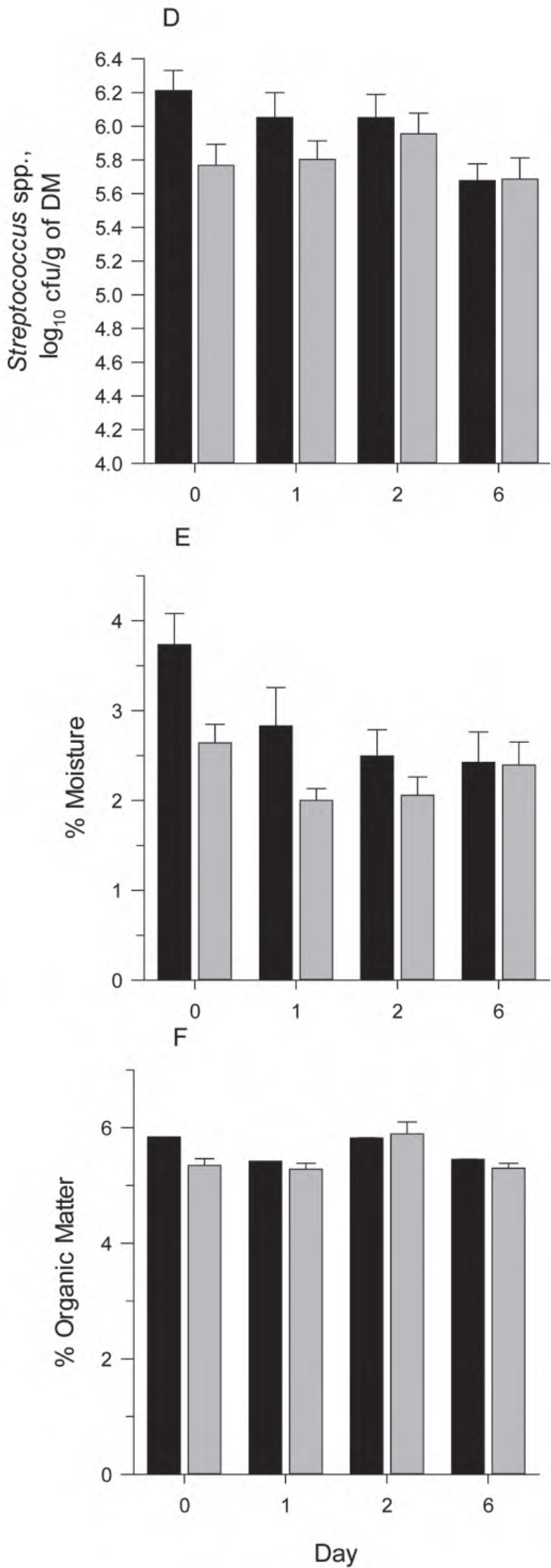

Figure 3. Counts of (A) gram-negative bacteria, (B) coliforms, (C) Klebsiella spp., (D) Streptococcus spp., (E) moisture, and (F) organic matter at a depth of 50 to $75 \mathrm{~mm}$ of untreated sand and sand treated with propane-fueled flame on d $0,1,2$, and 6 after use as bedding in freestalls. 
Moisture $(P<0.01)$ and $\mathrm{OM}(P<0.005)$ contents of flamed sand were decreased in the 50 to $75 \mathrm{~mm}$ layer immediately after treatment. Organic matter and moisture comparisons at other sample times and within bedding depths did not differ between flamed and control beddings $(P>0.05)$.

\section{Depth of Bedding}

Gram-negative bacteria, coliform, Klebsiella, and streptococcal counts were each reduced (Figure 4; $P<$ 0.05 ) in the surface $25 \mathrm{~mm}$ of bedding compared with the 50 to $75 \mathrm{~mm}$ samples on each sample day and independent of treatment. Likewise, the moisture content of bedding was reduced $(P<0.05)$ in the surface $25 \mathrm{~mm}$ of bedding compared with the 50 to $75 \mathrm{~mm}$ samples on each sample day in both flamed and control bedding. Organic matter content of bedding did not differ $(P>$ 0.05) among the different layers of bedding sampled.

\section{DISCUSSION}

A controlled field trial was conducted on a commercial dairy farm to determine the effects of propane flaming of sand bedding on bacteriological populations of common environmental mastitis pathogens. The daily movement of the propane flame at $3.2 \mathrm{~km} / \mathrm{h}$ over the surface of recycled sand bedding in stalls did provide a positive effect by reducing mastitis pathogen loads in recycled sand at different depths of bedding in a pathogen-specific manner. Streptococcal counts were reduced consistently in each of the 3 depths of sand tested. The reduction in streptococcal counts at 50 to $75 \mathrm{~mm}$ was comparable to that at 25 to $50 \mathrm{~mm}$ and the surface $25 \mathrm{~mm}$ of bedding. Gram-negative bacterial counts were also reduced in the surface $25 \mathrm{~mm}$ of sand and at the 50 to $75 \mathrm{~mm}$ depth. Klebsiella spp. counts were reduced only in the surface $25 \mathrm{~mm}$ of sand, but coliform counts differed between flamed and control sand bedding only at the 50 to $75 \mathrm{~mm}$ depth. Despite differences among bacterial groups, the greatest effects of flaming on mastitis pathogen populations were on the surface $25 \mathrm{~mm}$ of recycled sand. Reductions in bacterial counts at deeper depths were less consistent.

The effects of subsequent flaming of sand over a week also differed among pathogens. Streptococcal counts were reduced immediately after flaming on the day sand was added to stalls and remained lower $24 \mathrm{~h}$ later. However, the subsequent daily flaming of bedding over the next $6 \mathrm{~d}$ did not affect streptococcal counts. Klebsiella spp. counts were also reduced only immediately after the initial flaming and $24 \mathrm{~h}$ later.
Coliform counts were reduced by flaming immediately after flaming but did not differ at subsequent testing. Gram-negative bacterial counts differed between treatment groups only $24 \mathrm{~h}$ after the initial flaming. Mastitis pathogens were reduced the most in fresh sand, and flaming was less effective over the subsequent 6 -d period. The relative lack of persistency in antibacterial effects of flaming is consistent with previous attempts to reduce bacterial loads in organic bedding. Prior attempts to mediate the growth of bacterial populations in organic bedding required use of chemical bedding conditioners that reduced bacterial counts for less than $24 \mathrm{~h}$, but also left potential concern for environmental contamination (Hogan et al., 2007). An advantage to the use of propane flaming is the potential to serve as a clean and rapid antibacterial procedure without contaminating the environment when bedding is removed from the stalls. In contrast, the potential exists to cause unintentional harm while using an open flame to sanitize sand. Extreme caution was used in the present study to minimize danger to facilities, cows, and human operators.

The physical properties of sand (moisture and $\mathrm{OM}$ ) were altered less by flaming than were the bacteriological populations. Moisture and OM content did not differ between treatment groups within the surface $25 \mathrm{~mm}$ and 25 to $50 \mathrm{~mm}$ layers of sand. Flaming did decrease moisture and OM content of bedding in the 50 to 75 $\mathrm{mm}$ depth immediately after flaming, but had no effect on subsequent samples. The moisture content of sand was greatest in the 50 to $75 \mathrm{~mm}$ depth in freshly bedded sand and decreased in each layer of bedding during the week in both treated and control sand. The unexpected decrease in moisture content during the week was ascribed to evaporation during the warm, summer days, as observed previously (Kristula et al., 2005).

The depth from which sand samples were collected had an effect on bacteriological and moisture results, but not OM content. Gram-negative bacteria, coliform, Klebsiella, streptococcal counts, and moisture content were lower in the surface $25 \mathrm{~mm}$ of bedding compared with the 50 to $75 \mathrm{~mm}$ samples on each sample day and independent of treatment. The porous structure of sand particles allows for the percolation of moisture into lower depths of a sand pack and evaporation of moisture from the surface (Brady and Weil, 2008). As the moisture (Kristula et al., 2005) and nutrients (Godden et al., 2008) available are positively associated with bacterial growth in bedding, these differences between the surface and the deeper strata of sand bedding is logical. These results reinforce the need for care when collecting bedding to ensure consistency in sample depths when comparing bedding treatments and types. 
A
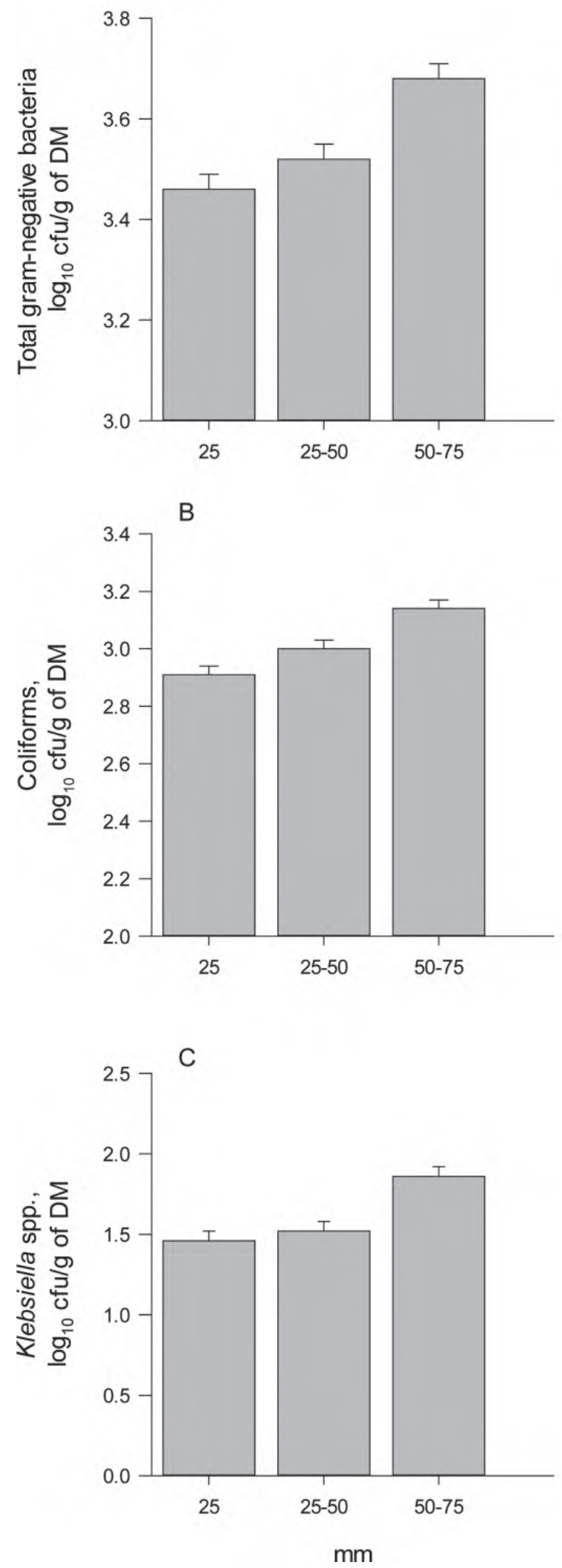

D

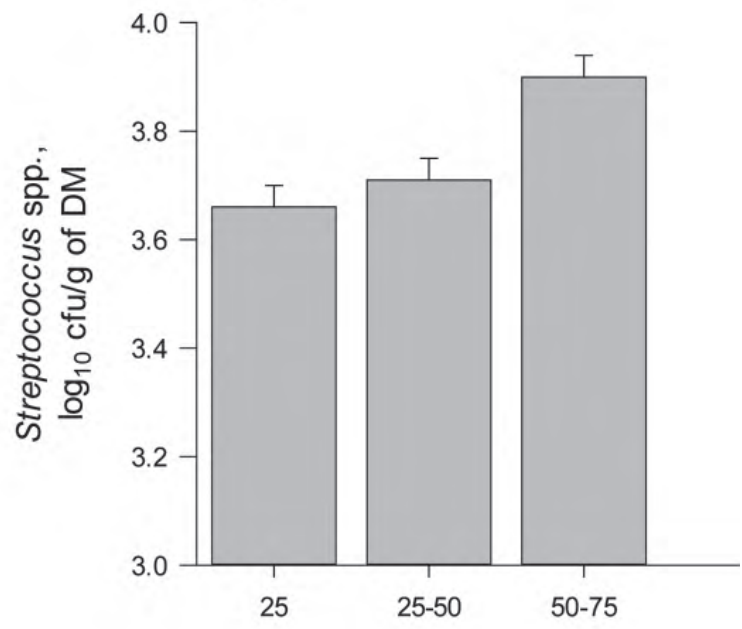

$\mathrm{E}$
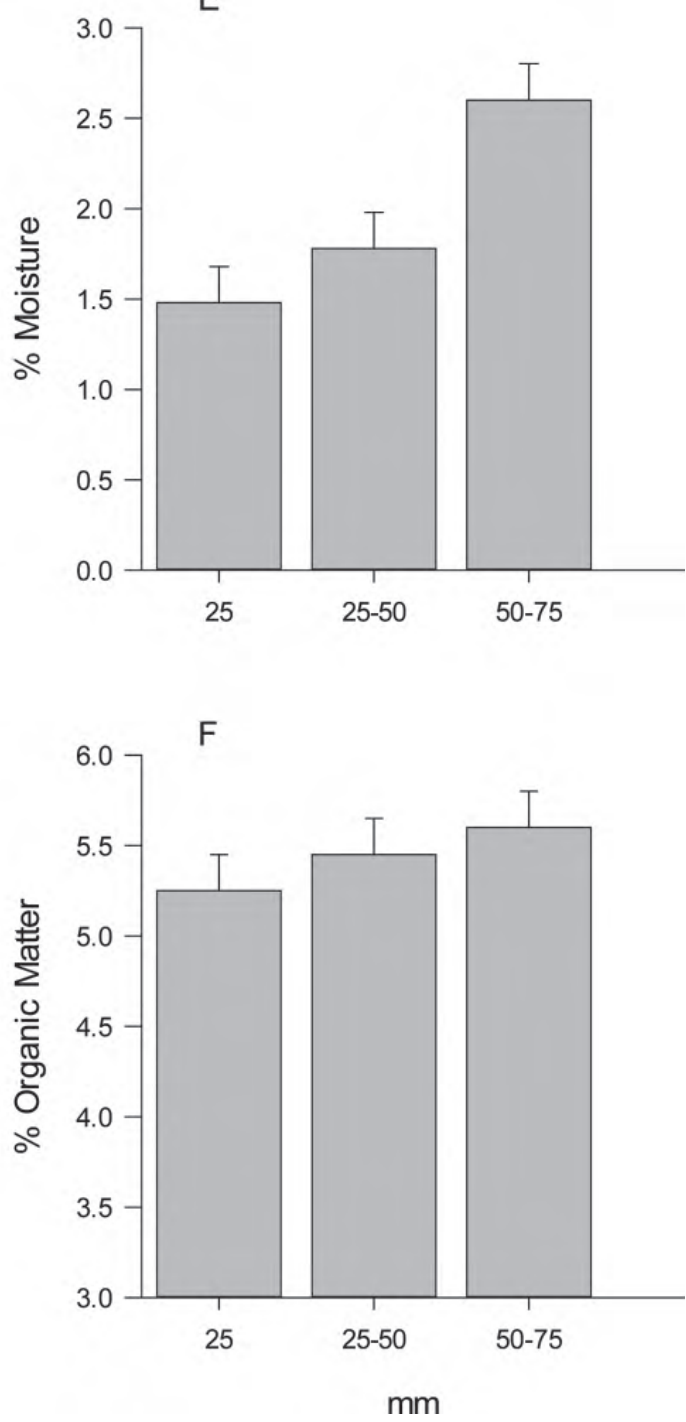

Figure 4. Combined counts of (A) gram-negative bacteria, (B) coliforms, (C) Klebsiella spp., (D) Streptococcus spp., (E) moisture, and (F) organic matter in the surface $25 \mathrm{~mm}$ and at depths of 25 to $50 \mathrm{~mm}$ and 50 to $75 \mathrm{~mm}$ of sand used as bedding in freestalls. 


\section{CONCLUSIONS}

Propane flaming reduced the populations of mastitis pathogens in recycled sand bedding. The greatest advantage afforded by flaming was on the surface of bedding, with inconsistent effects deeper in the sand. Flaming was more effective in controlling bacterial populations of fresh recycled sand than in sand after several days of use. Bacterial populations and moisture in bedding were lower in the surface $25 \mathrm{~mm}$ of sand bedding compared with sand at a depth of 50 to $75 \mathrm{~mm}$ in freestalls.

\section{ACKNOWLEDGMENTS}

This research was partially funded by the Propane Education \& Research Council (Washington, DC).

\section{REFERENCES}

Brady, N. C., and R. Weil. 2008. The Nature and Properties of Soils. 14th rev. ed. Prentice Hall Publishing, Upper Saddle River, NJ.
Godden, S., R. Bey, K. Lorch, R. Farnsworth, and P. Rapnicki. 2008. Ability of organic and inorganic bedding materials to promote growth of environmental bacteria. J. Dairy Sci. 91:151-159.

Hogan, J. S., and K. L. Smith. 1997. Bacterial counts in sawdust bedding. J. Dairy Sci. 80:1600-1605.

Hogan, J. S., K. L. Smith, K. H. Hoblet, D. A. Todhunter, P. S. Schoenberger, W. D. Hueston, D. E. Pritchard, G. L. Bowman, L. E. Heider, and B. L. Brockett. 1989. Bacterial counts in bedding materials used on nine commercial dairies. J. Dairy Sci. $72: 250-258$.

Hogan, J. S., S. L. Wolf, and C. S. Petersson-Wolfe. 2007. Bacterial counts in organic materials used as free-stall bedding following treatment with a commercial conditioner. J. Dairy Sci. 90:10581062.

Kristula, M. A., W. Rogers, J. S. Hogan, and M. Sabo. 2005. Comparison of bacteria populations in clean and recycled sand used for bedding in dairy facilities. J. Dairy Sci. 88:4317-4325.

Raffaelli, M., M. Fontanelli, C. Fransconi, F. Sorelli, and A. Peruzzi. 2010. Thermal disinfection of poultry grow-out facilities in centralnorthern Italy. Pages 1-8 in Proc. XVII World Cong. Intern. Commission Agric. Biosyst. Eng. Canadian Soc. Bioengineer., Québec City, QC, Canada.

SAS Institute. 2003. SAS User's Guide: Statistics. Version 9 ed. SAS Inst. Inc., Cary, NC.

Zdanowicz, M., J. A. Sheldford, C. B. Tucker, D. M. Weary, and M. A. G. Von Keyserligk. 2004. Bacterial populations on teat ends of dairy cows housed in free stalls and bedded with either sand or sawdust. J. Dairy Sci. 87:1694-1701. 